\title{
A STUDY ON CUSTOMER SATISFACTION ACROSS INFORMATION SEARCH BEHAVIOR TYPOLOGY
}

\author{
Wahyuningsih \\ Johnny Tanamal
}

This study investigates customer satisfaction based on a typology of consumer search behavior. The findings demonstrate that the type of consumer as defined by whether and how they search for information (passive, rational-active, and relational-dependent) has different level of satisfaction. Rational-active and relationaldependent consumers are found to be the dominant consumer types who actively search for information before purchasing a product and thus perceive a higher level of satisfaction than do passive consumers. The identification of satisfaction within each type of consumer provides a reason for customers to repurchase the same product, or recommend it to other people. As a result, companies will be able to achieve an increase in profitability. Recommendations for companies and future research directions are presented.

Keywords: consumer behavior typology; rational-active; relational-dependent; repeat-passive; satisfaction 
Gadjah Mada International Journal of Business, January - April 2008, Vol. 10, No. 1

\section{Introduction}

There have been an enormous number of studies which have investigated customer satisfaction (e.g. Athanassopoulos et al. 2001; BendallLyon and Powers 2004, Choi et al. 2004; Hansenmark and Albinsson 2004; Lam et al. 2004; Yang and Peterson 2004), so as Ueltschy et al. (2004) question: what more could be said about this concept? A possible answer to this query may be that satisfaction could be addressed by using or incorporating different approaches, for example by using geographic patterns in customer satisfaction (Mittal et al. 2004), and, as demonstrated in this study, by incorporating satisfaction with the typology of consumer search behavior. Hence, this study investigates customer satisfaction using a market segmentation approach, specifically information search behavior typology by Becket et al. (2000). This is because concentrating on the needs of homogeneous groups within a larger heterogeneous market assists companies to get closer to their consumers (Harrison 1994). The identification of satisfaction within each type of consumer provides a reason for customers to repurchase the same product, or recommend it to other people. As a result, companies will be able to achieve an increase in profitability.

This study examines the levels of satisfaction perceived by consumers linked back to their information search behavior. The main point addressed in this study is an investigation of judg- ment or evaluation "after" consumers purchasea product or service and linked that to a review of what the consumers did in terms of information search behavior. Thus, the examinations and analyses are focused on the relationship between consumers' search behavior and satisfaction and to test whether there are any differences in levels of satisfaction perceived by the three types of consumer search behavior. Subsequently, implications can be analyzed by approaching each type of consumer in order to optimize their levels of satisfaction.

\section{Literature Review}

\section{Customer Satisfaction}

Customer satisfaction has been considered by companies as a key strategic indicator of a company's success and long-term competitiveness (Law et al. 2004; Woodruff and Gardial 1996). It is so highly regarded that many service companies spend as much as half of their research budget on measuring customer satisfaction (Wilson 2002). Research of customer satisfaction has revealed several advantages for companies:

- A satisfied consumer is more likely to stay with the same company (Dick and Basu 1994; Fecikova 2004; Oliver 1997; Shankar et al. 2003)

- The longer a consumer stays with a company, the more products or services he/she purchases from the company (Law et al. 2004) 
- It costs more to capture a new consumer than to retain a current consumer (Peters 1988; Sheth et al. 1999)

- A satisfied consumer is less likely to switch to other companies (Gremler and Brown 1999; Keaveney 1995).

For these reasons, many organizations have placed much attention on studying customer satisfaction.

Furthermore, Anderson et al. (1994) and Fornell (1992) point out that higher customer satisfaction insulates current customers from competitors, enhances a firm's reputation in the marketplace, and lowers the costs of attracting and transacting with new customers. From the above advantages, accordingly, customer satisfaction leads to profitability (e.g. Anderson et al. 1997; Athanassopoulos et al. 2001; Moutinho and Smith 2000). Moreover, Rust and Zahorik (1993) have empirically tested the subsequent links of customer satisfaction, to individual loyalty, aggregate retention rate, market share, and profits. They also point out that retention rate is seen to be the most important component of market share, and that it is driven by customer satisfaction. This argument is supported by Kotler (1991) who argues that high customer satisfaction is the best indicator of a company's future profits. The reasons behind this argument may be stated as follows: when the customers perceive a high level of satisfaction, the result is positive evaluations. In this context, customers are assumed to continue doing business with the service provider, willing to engage in posi- tive word-of-mouth communication, and less likely to switch service providers. Consequently a company can retain their current customers and obtain new customers resulting from the word-of-mouth communications by the existing customers. Based on these advantages (greater probability in obtaining new customers and retaining the existing customers), the companies will achieve higher profits.

However, some counterarguments have arisen which argue that higher customer satisfaction does not necessarily result in higher repurchase and positive word-of-mouth communication. For example, Hennig-Thurau and Klee (1997) in line with Jones and Sasser (1995) point out that satisfaction is a poor predictor of loyalty and customer retention. Brandt (1997) also states that satisfaction scores have become an expensive end in themselves as a result of companies failing to link satisfaction measurements with customer loyalty, propensity to purchase, or profits. With regard to this view, the study by Anderson et al. (1997) finds two different results for goods and services. Their findings indicate that the association between changes in customer satisfaction, productivity, and profitability is positive for goods, but negative for services. The reasons for positive relationship between customer satisfaction and profitability have been elaborated above. Meanwhile, the negative relationship among customer satisfaction, productivity, and profitability occur when: (1) customer satisfaction is relatively more 
Gadjah Mada International Journal of Business, January - April 2008, Vol. 10, No. 1

dependent on customization (the degree to which the company's offering is customized to meet heterogeneous customers' needs) as opposed to standardization (the degree to which the company's offering is reliable, standardized, and free from deficiencies); and (2) when it is difficult (costly) to provide high levels of both customization and standardization simultaneously (Anderson et al. 1997). The negative relationship between customer satisfaction and profitability is mainly influenced by the technical strategies of the company. When the company is able to manage its strategies to suit the customers' needs, it will gain higher profits resulted from its satisfied customers.

\section{Defining Customer Satisfaction}

Customer satisfaction has been a popular topic in marketing for more than 30 years without the emergence of a consensual definition of the concept (Host and Knie-Andersen 2004). Johnson et al. (1995) argue that customer satisfaction is a cumulative construct that is affected by market expectations and performance perceptions in any given period, and is also affected by past satisfaction from period to period. This definition is supported by Fornell (1992) who defines customer satisfaction as a function of customer expectation and perceived performance. These definitions focus on expectations and performance as an instrumental construct of customer satisfaction.
According to Oliver (1980) satisfaction outcomes are a function of perceived performance and perceived disconfirmation. The author argues that perceived disconfirmation depends on perceived performance and a standard for comparison. Standards of comparison may include expectations, ideals, competitors, other service categories, marketer promises and industry norms. If perceived performance is significantly worse than the comparison standard, a customer will experience negative disconfirmation; in other words, products and services do not meet the comparison standard. This model has been further developed by Wirtz and Bateson (1999) by introducing uncertain performance expectations in satisfaction. It describes the impact of expected performance heterogeneity and level of disconfirmation on the satisfaction process. At higher levels of disconfirmation, uncertainty in expectations does not show any effect on disconfirmation levels; in contrast, at small levels of actual disconfirmation, the presence of uncertainty in expectationsimproves the level of disconfirmation, shifting it towards 'better than expected', and improving overall satisfaction. From this model, it can be noticed that there are three elements that influence the degree of consumer satisfaction; expectations, performance, and disconfirmation. These constructs have been used by many researchers in studying customer satisfaction (e.g. Anderson and Sullivan 1993; Churchill and Surprenant 1982; McQuitty et al. 2000). 
Wahyuningsih \& Tanamal-A Study on Customer Satisfaction Across Information Search Behavior Typology

Having reviewed the definitions of customer satisfaction in the literature, it is noticed that satisfaction is basically a post-consumption evaluation (Bolton et al. 2000), hence the definition of satisfaction used in this study is: "An overall post-purchase evaluation” (Fornell 1992: 11). This definition focuses on post-purchase perceived product performance compared with pre-purchase expectations.

\section{Consumer Behavior Search Typology}

Classifying target markets into groups of consumers assists marketers to clearly identify and satisfy the needs and wants of each group. This is based on the concept of market segmentation which states that "the process of market segmentation identifies groups of consumers who are similar to one another in one or more ways, and then devises marketing strategies that ap- peal to one or more groups" (Solomon 2002: 7). Similarly, Schiffman et al. (2001: 54) define market segmentation as "the process of dividing a market into distinct subsets of consumers with common needs or characteristics and selecting one or more segments to target with a distinct marketing mix".

In parallel with this view, Beckett et al. (2000) formulate a consumer behavior matrix (see Figure 1) that divide financial services consumers into four groups of consumers based on their behavior. The matrix is based on the work of Dwyer et al. (1987) concerning buyer-seller relationships and brings together a rich diversity of literature including economics (Simon 1957), consumer behavior (Bloch 1982; Bloch and Richins 1983), and psychology (Thibautand Kelley 1959).

According to Beckett et al. (2000), it is possible to identify consumer behavior through two principal factors

Figure 1. Consumer Behavior Matrix

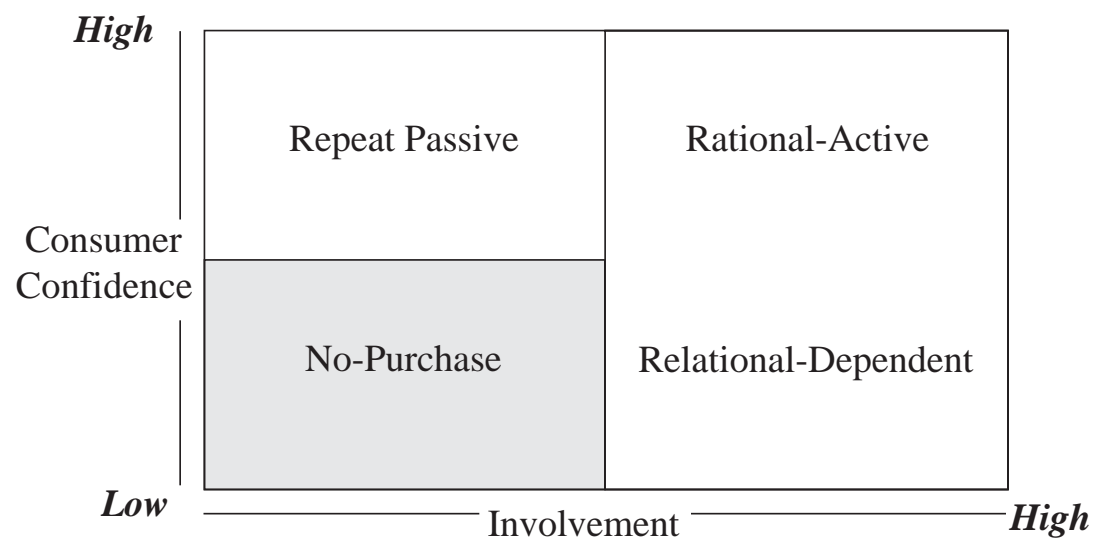

Sources: Beckett et al. (2000: 16) 
that motivate and determine individual contracting choices, namely involvement and uncertainty (Bateson 1989; McKechnie 1992; Harrison 1994; Ennew and McKechnie 1998). Consumer involvement incorporates a number of subsets: customer control (Bateson 1989), customer participation and level of contact (Chase 1978). Uncertainty or confidence is largely determined by perception of risk, which is determined by the complexity of the product being purchased and the certainty of the outcome associated with that product (Shostack 1977). Further discussion on involvement and confidence are presented on the following.

\section{Involvement}

The concept of involvement is defined as the relation between ego and an object (Sherif and Sherif 1967). The concept of involvement was first employed in studies of attitude change, and used in social judgment theory which postulates that an audience's response to a persuasive message is identified by two factors acting together; firstly, prior attitude toward the topic, secondly, involvement (Zaltman and Wallendorf 1983).

Zaichkowsky (1984) defines involvement as “a person's perceived relevance of the object based on their interest, needs, or values” (p.33). From a consumer behavior perspective, involvement has been defined as a motivational state of mind (arousal) that is goal directed (Zaltman and Wallendorf 1983). This indicates that there is a link between the level of a person's motivation towards a particulargoal and the level of involvement of that person(Aldlaigan and Buttle 2001; Harrison 1994). According to Mowen and Minor (1998) consumer involvement is "the perceived personal importance and/or interest consumers, attached to the acquisition, consumption, and disposition of a good, a service, or an idea." Hence, it is noticed that each consumer possesses a different level of involvement toward a product. In addition, according to Petty, Cacioppo, and Schumann (1983) involvement can be confounded with all other existing differences between the high and low involvement groups including the amount of information search. Parallel with this argument, level of confidence will be related to consumer information search behavior.

\section{Confidence}

Confidence has been frequently cited as an important construct for understanding consumer behavior (Bearden et al. 2001). Basically, the confidence construct was first proposed by Howard and Sheth (1969). They postulate that confidence is positively related to intentions. According to Howard (1989), confidence is the buyer's subjective certainty-his/her state of feeling sure - in making a judgment on the quality of a particular brand. In other words, confidence is the degree of certainty that one's evaluative judgment of the brand is correct.

The study done by Laroche et al. (1996) shows that intention to select an investment firm is a function of confi- 
Wahyuningsih \& Tanamal-A Study on Customer Satisfaction Across Information Search Behavior Typology

dence in one's evaluations of the firm. In addition, the work of Harrison (1994) on personal financial services, later supported by Ennew and McKechnie (1998), perceived confidence to be one of the aspects that should be considered in understanding consumers of the financial services market segment.

The consumers' level of confidence and involvement depend upon different classes of product being purchased. Hence, it impacts on different patterns of search behavior. For fastmoving consumer goods (FMCG), for example toothpaste, consumers may not need to have a high level of confidence and involvement; hence they do not need to search extensively before the purchase. Meanwhile, for abstract and very complex products, for ex- ample insurance, consumers may choose to search for information before purchasing the product.

From the key factors above, involvement and confidence, the matrix can be formulated (Figure 1). This matrix describes different types of consumer behavior: repeat-passive, rational-active, relational-dependent, and no-purchase. Based the work of Beckett et al. (2000), it is argued that there are only three types of consumer behavior:passive, rational-active, and relational-dependent. The "passive consumers" is taken from the "repeatpassive" consumers put forward by Beckett et al. (2000). However, repeat-passive can only occur when a consumer purchases a product for the second or subsequent times. Hence, the investigation is extended beyond

Figure 2. Types of Consumer

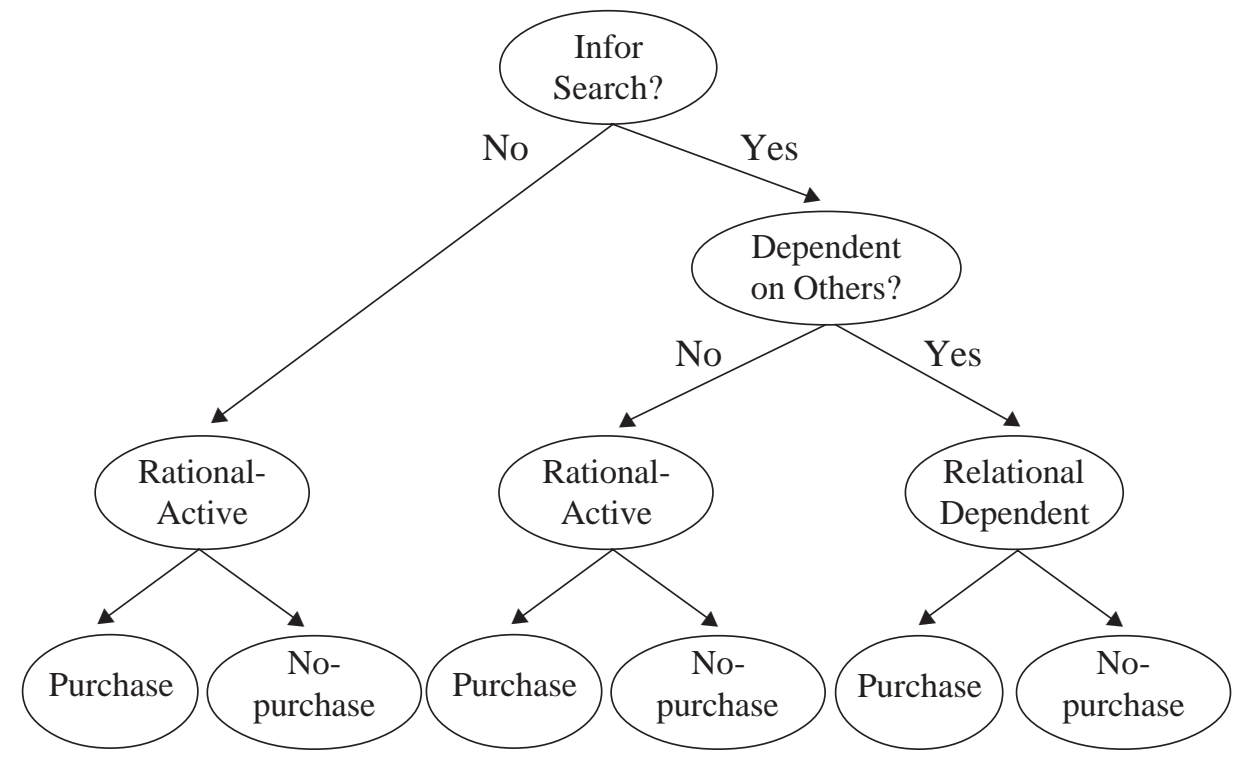

Source: Modified based on the study of Beckett et al. (2000). 
repeat buyers to include first-time buyers. In this study, first buyers and repeat buyers who are not actively searching for information prior to purchasing a product are known as passive.

Beckett et al. (2000) do not discuss the "no-purchase" consumers in their study. Instead, they focus on the three types of consumer behavior: repeat-passive, rational-active, and relational-dependent in the empirical discussion. We argue that, this is due to the fact that "no-purchase" is not a type of consumer; rather, it is an action outcome of one of the three types of consumer search (passive, rationalactive, and relational-dependent). Figure 2 shows how this works.

Based on the review above, a consumer will be categorized into "passive" if s/he:

- Does not search out information for alternative products or, in other words, s/he has a low level of information search.

This criterion is both necessary and sufficient for "passive" consumers.

A consumer will be categorized into "rational-active" if s/he:

- Actively searches out information for alternative products, or, in other words, s/he has a high level of information search.

- Is not directed by other people (friends, relatives, financial advisors) in the decision- making process.

The first criterion above is necessary but not sufficient to categorize a consumer as "rational-active.” To be sufficiently categorized as a "rational-active," the second criterion must also be fulfilled.

A consumer will be categorized into "relational-dependent" if s/he:

- Actively searches out information for alternative products, or, in other words, s/he has a high level of information search.

- Is strongly directed by other people (friends, relatives, and financial advisors) in the decision-making process.

Based on the above discussion, it is hypothesized that: different types of consumer behavior result in different levels of satisfaction for the same product.

\section{Methodology}

This study investigates the typology of consumer search behavior and the level of satisfaction displayed by each consumer type regarding their experiences with the car insurance industry. To collect these data, closedended questions in a structured questionnaire was used to capture the behavior, attitudes, and perceptions of consumers toward the product. The unit of analysis of this study is individuals, specifically, university students who have purchased car insurance in Melbourne, Australia.

Convenience samples of 654 questionnaires were distributed directly to respondents. Out of 654 questionnaires, 546 questionnaires were us- 
Wahyuningsih \& Tanamal-A Study on Customer Satisfaction Across Information Search Behavior Typology

able and 13 questionnaires were incomplete. Thus, the response rate in this survey was 85 percent.

The data analysis techniques used in this study are Analysis of Variance (ANOVA) and Structural Equation Modeling (SEM). ANOVA was used to compare the means of customer satisfaction in each of the consumer search behavior typology groups. SEM was employed to build and test the measurement model, which enables a comprehensive, confirmatory assessment of construct validity, and provides a confirmatory assessment of convergent validity and discriminant validity (Anderson and Gerbing 1988), as well as to test the relationship between customer satisfaction and behavioral intentions for each type of consumers. Since the concept of satisfaction will be investigated across different types of consumer (passive, rational-active, relational-dependent), the measurement/equivalence invariance (ME/I) using SEM needs to be performed. The purpose of testing ME/ I is to examine whether the conceptualization of satisfaction perceived is significantly similar by the different types of consumer (Vanderberg and Lance 1999). This is a prerequisite before researcher compares the means between groups.

\section{Measures Used in This Study}

This study uses existing scales for the measures of customer satisfaction including measures for multi-item scales(e.g. Athanassopoulos 2000) and direct measure (e.g. Spreng et al. 1996;
Fornell et al. 1996). The measures for consumer behavior typology were derived from the study of Beckett et al. (2000), and information search (e.g. Moorthy et al. 1997; Murray 1991; Urbany et. al. 1989).

Along with the increased researches of customer satisfaction, there has been an increase in the diversity of measurement scales used in customer satisfaction surveys (Devlin et al. 1993). Although numerous measurement scales have been proposed, these scales can be grouped into three broad categories: performance scales, for example poor, fair, good and excellent; disconfirmation scales, for example worse than expected to better than expected; satisfaction scales, for example very dissatisfied to very satisfied (Danaher and Haddrell 1996).

Following the measurement scales is the type of scale used in customer satisfaction surveys. From several studies in this field, there are two types of scale: single-item scales (e.g. Oliver 1977; Westbrook 1980) and multi-item scales (e.g. Athanassopoulos 2000; Chan et al. 2003). There have been some critics of the single-item scales. Yi(1990) claims that single item scales cannot assess or average out the variance due to random errors, specific items, and method factors. As a result, the reliability of single item scales is difficult to assess and even when assessed in some studies using the available test-retest reliability estimate, most estimates of this kind are low to moderate and it indicates that the scales should be used with caution (Yi 1990). 
Gadjah Mada International Journal of Business, January - April 2008, Vol. 10, No. 1

In single item scales, customers are solely asked about the overall evaluation of their service toward the products and services (Danaher and Haddrell 1996). Therefore, it is difficult to track what factors result in satisfied customers and which ones make the customers dissatisfied. On the other hand, multi-item scales do not only reveal the overall satisfaction but the customers are also asked to rate the key components of the service process (Danaher and Haddrell 1996). In addition, Chan et al. (2003) argue that multi-item scales are significantly more reliable than the single-item scale. Hence, in this study, customer satisfaction will be measured using both single item scales and multi item scales.

\section{Results}

Data on search behavior and sources of information are used to categorize consumers into three identified types of consumer behavior (pas- sive, rational-active, and relationaldependent). Based on the calculations that follow the defined typology of consumer behavior, the sample consists of 15 percent passive consumers, 38 percent rational-active consumers, and 47 percent relational-dependent consumers. We also asked the consumers what type of purchase they made. The result shows that 33 percent of consumers purchased car insurance for the first time (first buyer); 54 percent are consumers who purchased car insurance from the same company (renewed); and 13 percent are consumers who purchased car insurance from a different company (switched).

Results of testing ME/I for customer satisfaction across three group comparisons are presented in Appendix 1 . From this result, it is detected that the conceptualization of customer satisfaction has been perceived significant differently (nonequivalent) by consumers at the Strong Factorial Level (Model 3) as indi-

Table 1.Chi-Square Difference Test for Customer Satisfaction Construct at Strong Factorial Equivalence Level

\begin{tabular}{|c|c|c|c|c|c|c|c|c|}
\hline & $\chi^{2}$ & $d f$ & $\mathbf{p}$ & $\chi^{2 / d f}$ & $\Delta^{2}$ & $d f$ & ${ }^{2} / d f$ & $\mathbf{P}$ \\
\hline Baseline & 17.911 & 14 & .211 & 1.279 & & & & \\
\hline Corporate & 19.022 & 15 & .213 & 1.268 & 1.111 & 1 & 1.111 & $\mathrm{p}>.75$ \\
\hline Convenience & 18.754 & 15 & .225 & 1.250 & 0.843 & 1 & 0.843 & $\mathrm{p}>.75$ \\
\hline \multicolumn{9}{|c|}{ Innovativenessand } \\
\hline Pricing & 18.394 & 15 & .243 & 1.226 & 0.483 & 1 & 0.483 & $\mathrm{p}>.75$ \\
\hline Expectation & 19.458 & 15 & .194 & 1.297 & 1.547 & 1 & 1.547 & $\mathrm{p}>.25$ \\
\hline Feeling & 24.514 & 15 & .057 & 1.634 & 6.603 & 1 & 6.603 & $\mathrm{p}<.01$ \\
\hline
\end{tabular}


Wahyuningsih \& Tanamal-A Study on Customer Satisfaction Across Information Search Behavior Typology

Table 2. ANOVA: Consumer Behavior Search Typology and Satisfaction

\begin{tabular}{|c|c|c|c|c|c|}
\hline & $\begin{array}{c}\text { Passive } \\
(\mathrm{N}=79)\end{array}$ & $\begin{array}{c}\text { Rational- } \\
\text { Active } \\
(\mathrm{N}=208)\end{array}$ & $\begin{array}{c}\text { Relational- } \\
\text { Dependent } \\
(\mathrm{N}=259)\end{array}$ & F-Ratio & Sig. \\
\hline Multi-item Scale & 4.3448 & 4.6895 & 4.5323 & 5.274 & .005 \\
\hline Single-item Scale & 5.8800 & 6.1985 & 6.0369 & 4.209 & .015 \\
\hline Total Satisfaction* & 5.1124 & 5.4440 & 5.2858 & 7.197 & .001 \\
\hline
\end{tabular}

*Total Satisfaction is the average of multi-item scale and single-item scale

cated by the significant p value $(\mathrm{p}<.05)$. Therefore, further investigation is needed to determine what variable(s) are perceived non-equivalent by consumers. As there are five main variables for measuring satisfaction (corporate, convenience, innovative-commission, expectation, and feeling), the chi-square difference test was performed on each variable (see Table 1 ).

The above chi-square difference test shows that the four variables: corporate, convenience, innovative-commission, expectation have been perceived similarly (equivalent) by consumers. In other words, only "feeling” that has been perceived to be significantly different (non-equivalent) by consumers. Therefore, it can be concluded that "corporate, convenience, innovativeness-pricing, and expectation" can be generalized to measuring customer satisfaction across types of consumer.

Following from the above result (Table 1), the measurement equivalence/invariance test needed to be reperformed, excluding the "feeling" variable as it was detected that this item was perceived by consumers to be non-equivalent (see Appendix 2). The following result shows that without "feeling" variable, the conceptualization of customer satisfaction has been perceived as equivalent by the three groups of consumer as indicated by the non-significant of all the p value. Based on this result, crossgroup comparisons using ANOVA can be conducted (presented in Table 2).

The results indicate that the three types of consumer behavior perceive significantly different levels of satisfaction (Sig. is .001), whether it is measured using multi-item scales (Sig. is .005) or single-item scales (Sig. is .015). Moreover, it is found that rational-active consumers perceived the highest levels of satisfaction (MEAN 5.4440) compared to relational dependent consumers (MEAN 5.2858). Passive consumers perceived the lowest levels of satisfaction (MEAN 5.1124).

This study also investigates whether consumers who have made a claim perceive different levels of satisfaction from those who have not. The result from ANOVA (see Table 3) 
Gadjah Mada International Journal of Business, January - April 2008, Vol. 10, No. 1

Table 3. ANOVA: Claims Statement and Customer Satisfaction ( $=546)$

\begin{tabular}{|c|c|c|c|c|}
\hline & $\begin{array}{c}\text { Yes* } \\
(\mathrm{N}=140)\end{array}$ & $\begin{array}{c}\text { No** } \\
(\mathrm{N}=406)\end{array}$ & F-Ratio & Sig. \\
\hline Multi-item Scale & 4.5687 & 4.5647 & 1.550 & .214 \\
\hline Direct Measure & 6.2252 & 6.0620 & .001 & .975 \\
\hline Total Satisfaction & 5.3969 & 5.3133 & .647 & .422 \\
\hline
\end{tabular}

* Yes = Consumer who Made a Claim with the Current Company

**No $=$ Consumer who have NOT Made a Claim with the Current Company

indicates that there is non-significant difference on levels of satisfaction perceived by consumers who have made a claim and who have not (Sig. 422). It shows that whether consumers have made a claim or not, they perceived the same level of satisfaction.

\section{Discussion}

The results from typology of consumer behavior indicate that the dominant types of consumer are relationaldependent and rational-active. This applies to all consumers across three types of purchase: first buyer, renewed, and switched. Because the respondents in this study are students, it makes sense that there should be a substantial proportion of first buyers. It also makes sense that; since these are "young consumers" they are more likely to be reliant on others to help them with their choices. This finding is in accordance with the studies of Holstius and Kaynak (1995), Almossawi (2001), and Devlin (2002) which point out that recommendation of friends and relatives is considered as one of the most important factor for consumers in choosing financial service. Moreover, it is found that young consumers are very active in terms of searching for information. This is due to the fact that consumers have different levels of knowledge about products and brands, depending on their personal experiences (Mattila and Wirtz 2002). In this case, young consumers have less experience compared to adult consumers who have been purchasing car insurance for many years. These differences in knowledge and experience generate important implications for consumers' pre-purchase information search activities. Accordingly, young consumers are very active in collecting information before purchasing a product.

The results indicate that the levels of satisfaction perceived by each of the three types of consumer are significantly different (see Table 2). Rational-active and relational dependent consumers perceived higher levels of satisfaction compared to passive consumers. One explanation may be that active consumers have searched for sufficient information before purchasing the product and feel confident about 
Wahyuningsih \& Tanamal-A Study on Customer Satisfaction Across Information Search Behavior Typology

their purchase. That is, before they decided to purchase a particular product, they compared the product with other available products. As a result, the level of satisfaction they perceived would be higher. In contrast, passive consumers did not collect enough information to make these comparisons and therefore, they may not be as satisfied with their choice as rationalactive and relational-dependent consumers.

In the context of car insurance, levels of satisfaction perceived by consumers may also be affected by whether or not consumers have had experience with claim settlement. In other words, consumers who have not filed a claim settlement with the company may not be able to adequately express their level of satisfaction in comparison to consumers who have filed a claim settlement. Therefore, it is suggested that further investigation is conducted whether levels of satisfaction are affected by consumers' experience of filing a claim.

It is found that there is a nonsignificant difference on claim settlement and consumers' level of satisfaction (see Table 3). This means that, consumers, whether they have or have not filed a claim settlement perceive the same levels of satisfaction. The implication for service providers is that, they have no need to differentiate between consumers who have made a claim and those who have not. This is because consumers who have no experience with claim settlement perceived the same levels of satisfaction as the consumers who have filed claims settlement. Service providers need to improve attributes of satisfaction such as convenience and accessibility, and deliver them in the same way, to consumers who have and have not filed a claim.

Meanwhile, companies need different approaches in managing a customer satisfaction program for the three different types of consumers since these three types of consumer perceive their levels of satisfaction differently. Furthermore, companies need to identify each segment of consumers whether they are passive, rational-active, or relational-dependent consumers. The findings suggest that rational-active and relational dependent consumers are very sensitive about their feelings and expectations and hence more sensitive to the marketplace; companies need to communicate continuously with these groups and increase their performance. Companies have to use specific strategies to communicate their offerings to passive consumers since these consumers are less sensitive to the marketplace.

Companies need to identify the determinants of satisfaction including consumers' expectations and to develop appropriate strategies targeting rational-active and relational-dependent consumers. The justification for such an approach is, as noted in the previous paragraph, these consumers are very sensitive about their feelings and expectations, thus very sensitive to market change. If a company cannot meet the expectations of these two 
types of customers, they will quickly perceive low levels of satisfaction. Consequently, those customers may switch to other companies; hence, decreasing company's profit.

\section{Conclusion, Limitations and Future Research Directions}

This is the first study which examines the levels of satisfaction perceived by consumers linked back to their information search behavior. The examination and analysis are focused on the relationship between consumers' search behavior and satisfaction and whether or not there are any differences in levels of satisfaction perceived by the three types of consumer search behavior. The findings suggest that the three types of consumer as defined by whether and how they search for information (passive, rational-active, relational-dependent) perceive their levels of satisfaction differently. Hence, to satisfy their customers, companies need to identify clearly each segment of consumers whether they are passive, rational-active, or relational-dependent consumers. Since rational-active and relational dependent consumers are very sensitive about their feelings and expectations, companies need to communicate and increase their performance continuously. This will affect the overall satisfaction the consumers perceived.

The findings suggest that rational-active and relational-dependent consumers are more sensitive to the market place. These consumers are very sensitive to changes in both the benefits being offered by companies and the sacrifices they have to make. For example, if there is a change in the premium cost applied by a car insurance company, rational active and relational dependent consumers will notice this change and it will have a sizable impact on the perceived sacrifices. This will then have an effect on these consumers' decision as to which car insurance company to choose. Meanwhile, passive consumers are less sensitive to the market place. They may not be concerned about what a company is offering. The implication here is that, passive consumers might present both an opportunity and a challenge for the company; the opportunity is that the company might earn more profits from these consumers since they are not concerned about what other companies are offering; the challenge is that the company have to find a way to persuade passive consumers who are a competitor's customers to become relational-dependent or active consumers in order to choose the product offered by the company over their competitor's products. Meanwhile, for rational-active consumers, managers need to be very systematic and detailed when informing these consumers of the benefits their company offers. For relational-dependent consumers, managers might develop better strategies for managing reference groups, family members, and opinion leaders. The people on whom relational-dependent consumer rely for advice tend to be rational-active them- 
Wahyuningsih \& Tanamal-A Study on Customer Satisfaction Across Information Search Behavior Typology

selves. Satisfying consumers based on a market segmentation approach will allow companies to get closer to their customers, which should result in repeat purchase, and positive word-ofmouth communication. Consequently, companies will achieve better financial performance.

This study suggests that research into customer satisfaction across groups must establish measurement equivalence. This study found that the "feeling" variable as one of the measures of customer satisfaction was perceived to be significantly different by different groups' consumers. By excluding this variable, the measure of customer satisfaction has been perceived to be not significantly different (equivalent) by the three groups of consumer. This finding suggests that further researches into measurement equivalence across groups should reveal whether any variable(s) or item(s) of the measures cannot be generalized across groups. Those specific variable(s) that cannot be generalized should be used with caution or eliminated.
This study has some limitations that should be addressed by future researches. Firstly, the unit of analysis of the study is students, which may be limited to specific characteristics of respondents. Hence, the finding indicates that there are a substantial proportion of relational-dependent consumers, which means that they are actively searching for information before the purchase and directed by other people in making the decision to purchase the product. It might be useful to replicate this study, perhaps in other service industries using mass market consumers as the respondents to examine whether the findings are consistent. In other words, to enhance the generalizability of the findings.

Secondly, this study has employed car insurance as its context, which might require consumers to search for information before purchasing the product. Hence, the conceptual model of this study might well be applied in consumer search in complex or intangible products, which may not be so well applied in fast-moving consumer goods (FMCG).

\section{References}

Aldlaigan, A. H., and F. A. Buttle. 2001. Consumer involvement in financial services: An empirical test of two measures. International Journal of Bank Marketing 19 (6): 232245.

Almossawi, M. 2001. Bank selection criteria Employed by college students in Bahrain: An empirical analysis. International Journal of Bank Marketing 19 (3): 115-125.

Anderson, E. W., and C. Fornell. 1994. A framework for comparing customer satisfaction across individual and product categories. Journal of Economic Psychology, 12, 267286. 
Gadjah Mada International Journal of Business, January - April 2008, Vol. 10, No. 1

Anderson, E. W., and M. W. Sullivan. 1993. The antecedents and consequences of customer satisfaction for firms. Marketing Science 12 (2): 125-143.

Anderson, J. C., and D. W. Gerbing. 1988. Structural equation modeling in practice: A review and recommended two-step approach. Psychological Bulletin 103 (3): 411423.

Athanassopoulos, A. D. 2000. Customer satisfaction cues to support market segmentation and explain switching behavior. Journal of Business Research 47 (3 March): 191207.

Athanassopoulos, A. D., S. Gounaris, and V. Stathakopoulos. 2001. Behavioral responses to customer satisfaction: An empirical study. European Journal of Marketing 35 (5/ 6): 687-707.

Bateson, J. E. G. 1989. Managing Services Marketing: Text and Readings ( $2^{\text {nd }}$ ed.). The USA: Dryden Press.

Bearden, W. O., D. M. Hardesty, and R. L. Rose. 2001. Consumer self-confidence: Refinements in conceptualization and measurement. Journal of Consumer Research 28 (June): 121-134.

Beckett, A., P. Hewer, and B. Howcroft. 2000. An exposition of consumer behavior in the financial services industry. International Journal of Bank Marketing 18 (1): 15-26.

Bendall-Lyon, D., and T. L. Powers. 2004. The impact of structure and process attributes on satisfaction and behavioral intentions. Journal of Services Marketing 18 (2): 114121.

Bloch, P. 1982. Involvement beyond the purchase process: Conceptual issues and empirical investigation. Advances in Consumer Research 9 (1): 413-417.

Bloch, P., and M. L. Richins. 1983. A theoretical model for the study of product importance perceptions. Journal of Marketing 47 (3): 69-81.

Bolton, R. N., P. K. Kannan, and M. D. Bramlett. 2000. Implications of loyalty program membership and service experiences for customer retention and value. Journal of the Academy of Marketing Science 28 (1): 95-108.

Brandt, R. 1997. Satisfaction studies must measure what the customer wants and expects. Marketing News 31 (22): 17-18.

Chan, L. K., Y. V. Hui, H. P. Lo, S. K. Tse, G. K.F. Tso, and M. L. Wu. 2003. Consumer satisfaction index: New practice and findings. European Journal of Marketing 37 (5/ 6): 872-911.

Chase, R. B. 1978. Where does the customer fit in a service organization. Harvard Business Review 56 (6): 137-142.

Choi, K-S., W-H Cho, S. Lee, H. Lee, and C. Kim. 2004. The relationships among quality, value, satisfaction and behavioral intention in health care provider choice: A south Korean study. Journal of Business Research 57: 913-921.

Churchill, G. A., and C. Surprenant. 1982. An investigation into the determinants of customer satisfaction. Journal of Marketing Research 19 (November): 491-504.

Danaher, P. J., and R. W. Gallagher. 1997. Modeling customer satisfaction in Telecom New Zealand. European Journal of Marketing 31 (2): 122-133. 
Wahyuningsih \& Tanamal-A Study on Customer Satisfaction Across Information Search Behavior Typology

Danaher, P. J., and V. Haddrell. 1996. A comparison of question scales used for measuring customer satisfaction. International Journal of Service Industry Management 7 (4): 4-26.

Devlin, J. F. 2002. Customer knowledge and choice criteria in retail banking. Journal of Strategic Marketing 10 (4): 273-290.

Devlin, S. J., H. K. Dong, and M. Brown. 1993. Selecting a scale for measuring quality. Marketing Research: A Magazine of Management and Applications 5 (3): 12-17.

Dick, A. S., and K. Basu. 1994. Customer loyalty: Toward an integrated conceptual framework. Journal of the Academy of Marketing Science 22 (2): 99-113.

Dwyer, F. R., P. H Schurr, and S. Oh. 1987. Developing buyer-seller relationships. Journal of Marketing 51 (April): 11-27.

Ennew, C., and S. McKechnie. 1998. The financial services consumer. In M. Gabbott, and Hogg, G., (Ed.), Consumers and Services. Chichester: John Wiley and Sons.

Fecikova, I. 2004. An index method for measurement of customer satisfaction. TQM Magazine 16 (1): 57-68.

Fornell, C. 1992. A national customer satisfaction barometer: The Swedish experience. Journal of Marketing 56 (1): 6-21.

Fornell, C., M. D. Johnson, E. Anderson, J. Cha, and B. E. Bryant. 1996. The American customer satisfaction index: Nature, purpose, and findings. Journal of Marketing 60 (October): 7-18.

Gremler, D. D., and S. W. Brown. 1999. The loyalty ripple effect: Appreciating the full value of customers. International Journal of Service Industry Management 10 (3): 271-291.

Hansenmark, O. C., and M. Albinsson. 2004. Customer satisfaction and retention: The experiences of individual employees. Managing Service Quality 14 (1): 40-57.

Harrison, T. S. 1994. Mapping customer segments for personal financial services. International Journal of Bank Marketing 12 (8): 17-25.

Hennig-Thurau, T., and A. Klee. 1997. The impact of customer satisfaction and relationship quality on customer retention: A critical reassessment and model development. Psychology and Marketing 14 (8): 737-764.

Holstius, K., and E. Kaynak. 1995. Retail Banking in Nordic Countries: The Case of Finland,” International Journal of Bank Marketing 13 (8), 10-20.

Host, V. and M. Knie-Andersen. 2004. Modeling customer satisfaction in mortgage credit companies. The International Journal of Bank Marketing 22 (1): 26-42.

Howard, J. 1989. Consumer Behavior in Marketing Strategy. Englewood Cliffs, NJ: Prentice Hall.

Howard, J., and J. Sheth. 1969. The Theory of Buyer Behavior. The USA: John Wiley and Sons.

Johnson, M. P., E. W. Anderson, and C. Fornell. 1995. Rational and adaptive performance expectations in a customer satisfaction framework. Journal of Consumer Research 21 (March): 695-707. 
Gadjah Mada International Journal of Business, January - April 2008, Vol. 10, No. 1

Jones, T. O., and W.E. Sasser. 1995. Why satisfied customers defect. Harvard Business Review 73 (6): 88-99.

Keaveney, S. M. 1995. Customer switching behavior in service industries: An exploratory study. Journal of Service Marketing 15 (4): 300-321.

Kotler, P. 1991. Marketing Management: Analysis, Planning, Implementation, and Control ( $7^{\text {th }}$ ed.). Englewood Cliffs, N.J.: Prentice-Hall.

Lam, S. Y., V. Shankar, M. K. Erramilli, and B. Murthy. 2004. Customer value, satisfaction, loyalty, and switching costs: An illustration from a business-to-business service context. Journal of the Academy of Marketing Science 32 (3): 293-311.

Laroche, M., C. Kim, and L. Zhou. 1996. Brand familiarity and confidence as determinants of purchase intention: An empirical test in a multiple brand context. Journal of Business Research 37: 115-120.

Law, A. K. Y., Y. V. Hui, and X. Zhao. 2004. Modeling repurchase frequency and customer satisfaction for fast food outlets. International Journal of Quality and Reliability Management 21 (5): 545-563.

Mattila, A., and J. Wirtz. 2002. The impact of knowledge structures on consumer search processes. International Journal of Service Industry Management 13 (3/4): 214-230.

McKechnie, S. 1992. Consumer buying behaviour in financial services: An overview. International Journal of Bank Marketing 10 (5): 4-14.

McQuitty, S., A. Finn, and J. B. Wiley. 2000. Systematically varying consumer satisfaction and its implication for product choice. Academy of Marketing Science Review. http:/ /www.amsreview.org/theory/mcquitty10-00.html.

Mittal, V., W. A. Kamakura, and R. Govind. 2004. Geographic patterns in customer service and satisfaction: An empirical investigation. Journal of Marketing 68 (July): 48-62.

Moorthy, S., B. T. Ratchford, and D. Talukdar. 1997. Consumer information search revisited: Theory and empirical analysis. Journal of Consumer Research 23 (March): 263-279

Moutinho, L., and A. Smith. 2000. Modelling bank customer satisfaction through mediation of attitudes towards human and automated banking. International Journal of Bank Marketing 18 (3): 124-134.

Mowen, J. C., 1995. Consumer Behavior (4th ed.). Englewood Cliffs, N.J.: Prentice-Hall.

Mowen, J. C, and M. Minor. 1997. Consumer Behavior ( $5^{\text {th }}$ ed.). London: Prentice-Hall.

Murray, K. B. 1991. A test of services marketing theory: Consumer Information Acquisition Activities. Journal of Marketing 55 (1): 10-25.

Oliver, R. L. 1980. A cognitive model of the antecedents and consequences of satisfaction decisions. Journal of Marketing Research 17 (September): 46-49.

Oliver, R. L. 1997. Satisfaction: A Behavioral Perspective on the Consumer. New York: McGraw-Hill.

1977. 1977. Effect of expectation and disconfirmation on post-exposure product evaluations: An alternative interpretation. Journal of Applied Psychology 62 (August): 480486. 
Wahyuningsih \& Tanamal-A Study on Customer Satisfaction Across Information Search Behavior Typology

Peters, T. 1988. Thriving on Chaos. New York: Alfred A. Knopf.

Petty, R. E., J. T. Cacioppo, and D. Schumann. 1983. Central and peripheral routes to advertising effectiveness: The moderating role of involvement. Journal of Consumer Research 10 (September): 135-146.

Rust, R. T., and A. J. Zahorik. 1993. Customer satisfaction, customer retention, and market share. Journal of Retailing 69 (2): 193-215..

Schiffman, L., D. Bednall, E. Cowley, A. O’Cass, J. Watson, and L. Kanuk. 2001. Consumer Behaviour. Australia: Prentice-Hall.

Shankar, V., A. K. Smith, and A. Rangaswamy. 2003. Customer satisfaction and loyalty in online and offline environments. International Journal of Research in Marketing 20 (2): 153-175.

Sheth, J. N, B. Mittal, and B. I. Newman. 1999. Customer Behavior: Consumer Behavior and Beyond. The USA: The Dryden Press.

Sheth, J. N, B. I. Newman, and B. L. Gross. 1991. Consumption Values and Market Choice. Cincinati, Ohio: South Western Publishing.

Sherif, M., and C. W. Sherif. 1967. Attitude as the individual's own categories: The social judgment-involvement approach to attitude and attitude change. In Carolyn W. Sherif, and Sherif, Muzafer (Ed.), Attitude, Ego-Involvement and Change. New York: John Wiley \& Sons.

Shostack, L. G. 1977. Breaking free from product marketing. Journal of Marketing 41 (2): 73-80.

Simon, H. A. 1957. Models of Man. New York: John Wiley.

Solomon, M. R. 2002. Consumer Behavior: Buying, Having, and Being ( $5^{\text {th }}$ ed.). New York: Prentice-Hall.

Spreng, R. A, S. B. Mackenzie, and R. W. Olshavsky. 1996. A reexamination of the determinants of consumer satisfaction. Journal of Marketing 60 (3): 15-32.

Thibaut, J. W., and H. H. Kelley. 1959. The Social Psychology of Groups. New York: John Wiley \& Sons Inc.

Ueltschy, L. C., M. Laroche, R. D. Tamilia, and P. Yannopoulos. 2004. Cross-cultural invariance of measures of satisfaction and service quality. Journal of Business Research 57 (8): 901-912.

Urbany, J. E., P. R. Dickson, and W. L. Wilkie. 1989. Buyer uncertainty and information search. Journal of Consumer Research 16 (September): 208-215.

Vanderberg, R. J., and C. E. Lance. 2000. A review and synthesis of the measurement invariance literature: Suggestions, practices, and recommendations for organizational research. Organizational Research Methods 3 (1): 4-70.

Westbrook, R. A. 1980. Intrapersonal affective influences on customer satisfaction with products. Journal of Consumer Research 7 (June): 49-54.

Wilson, A. 2002. Attitudes towards customer satisfaction measurement in the retail sector. The Market Research Society 44 (2): 213-221. 
Gadjah Mada International Journal of Business, January - April 2008, Vol. 10, No. 1

Wirtz, J., and J. E. G. Bateson. 1999. Introducing uncertain performance expectations in satisfaction models for services. International Journal of Service Industry Management 10 (1): 82-99.

Woodruff, R. B., and S. F. Gardial. 1996. Know Your Customer: New Approaches to Understanding Customer Value and Satisfaction. Cambridge, The USA: Blackwell Publishers.

Yang, Z., and R. T. Peterson. 2004. Customer perceived value, satisfaction, and loyalty: The role of switching costs. Psychology and Marketing 21 (10) (October): 799-822.

Yi, J. 1990. A critical review of consumer satisfaction. In V. A. Zeithaml (Ed.), Review of Marketing. Chicago: American Marketing Association.

Zaichkowsky, J. L. 1984. Conceptualizing and measuring the involvement construct in marketing. PhD Dissertation. University of California, Los Angeles.

Zaltman, G. and M. Wallendorf. 1983. Consumer Behavior: Basic Findings and Management Implications. New York: John Wiley \& Sons. 
Wahyuningsih \& Tanamal-A Study on Customer Satisfaction Across Information Search Behavior Typology

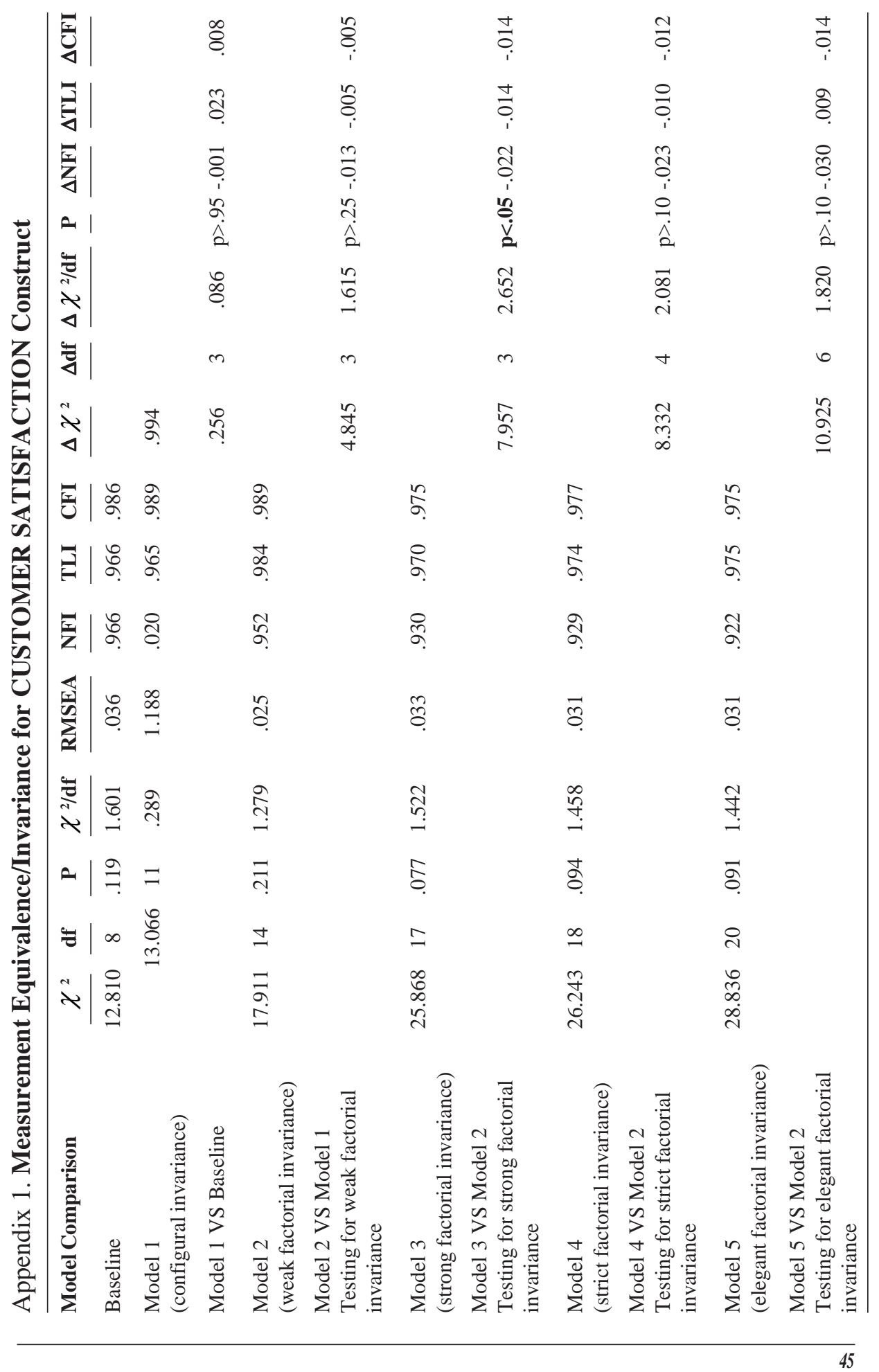


Gadjah Mada International Journal of Business, January - April 2008, Vol. 10, No. 1

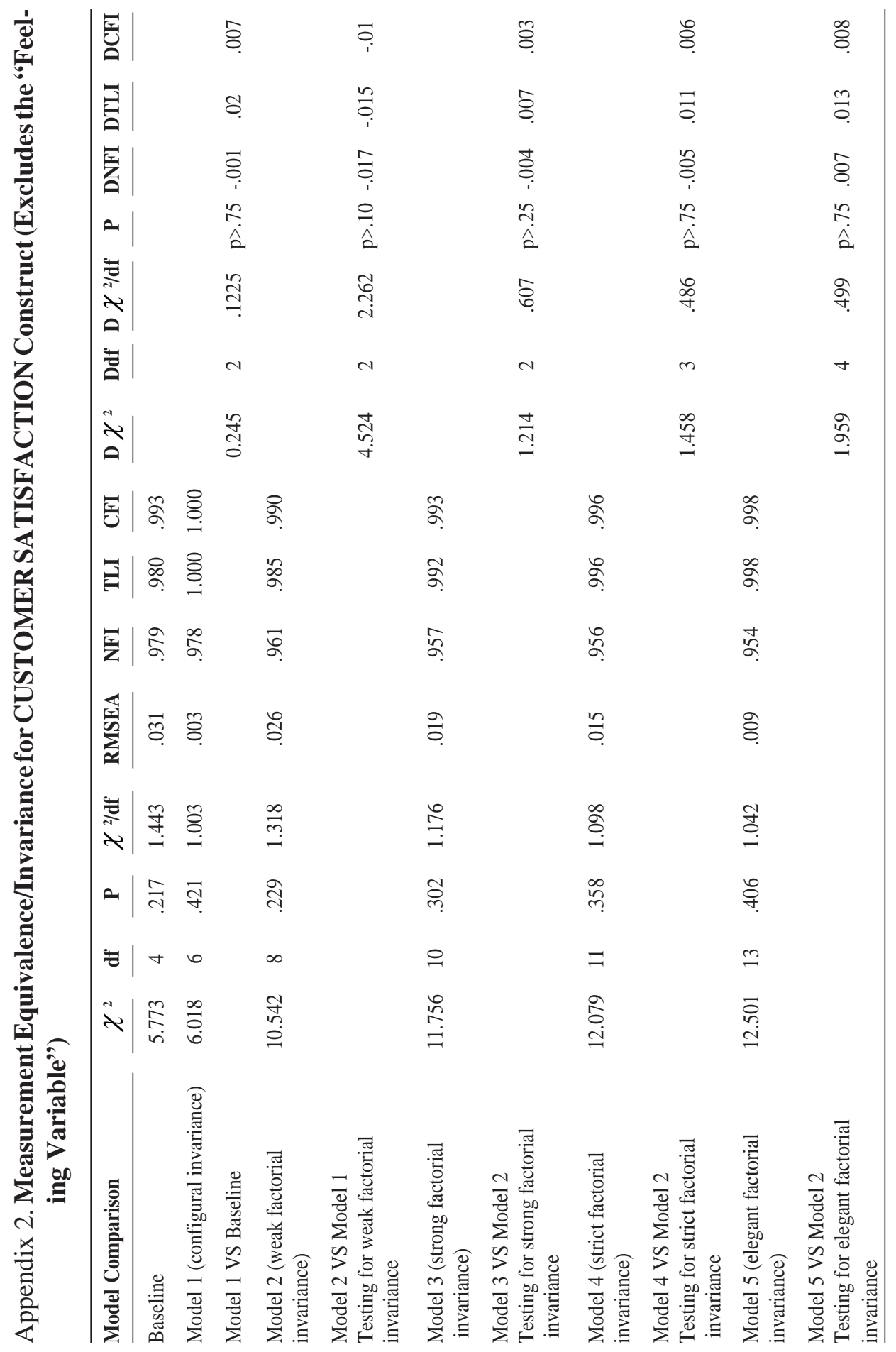

